\title{
Idiopathic: Prenatal closure of the ductus arteriosus causing fetal hydrops
}

\author{
Sandeep M ${ }^{1 *}$, Patil US ${ }^{2}$, Pawer RS ${ }^{3}$ and Gavade VK ${ }^{4}$ \\ ${ }^{1}$ Consultant Pediatric Cardiologist, Masai Childrens Hospital, Kolhapur, Maharashtra, India \\ ${ }^{2}$ Resident Masai Childrens Hospital, Kolhapur, Maharashtra, India \\ ${ }^{3}$ Consultant Neonatologist, Masai Children Hospital, Kolhapur, Maharashtra, India \\ ${ }^{4}$ Superintendent \& HOD, Masai Childrens Hospital, Kolhapur, Maharashtra, India
}

\begin{abstract}
Spontaneous premature closure of the human fetal ductus arteriosus is an uncommon event that often results in significant morbidity and mortality. We present a case of a neonate with prenatal previously not detected intrauterine closure of the ductus arteriosus to 21-year-old, Consanguinity type 2, G3P1A2L1 at 39 weeks of gestation, with previous scan showing placenta previa grade 1 at 21 weeks and Doppler study showing pericardial effusion at 36 weeks.Cesarean section was performed in view of absent progression of labour. A male new-born weighing $4100 \mathrm{gm}$, with bag and mask and intubation required, respectively. With an excellent neonatal outcome. Finally we suggest that fetal echo in third trimester \& maternal education programs to avoid self-medication and provide training for good diet is necessary.
\end{abstract}

\section{Introduction}

Intrauterine ductus arteriosus closure is a rare occurrence which has not been fully explored. It is usually hard to diagnose [1] and both its incidence and prognosis are unknown [2]. Prostaglandin inhibitors such as indomethacin are effective tocolytic agents and may be used to prevent premature labor [3]. However, it is well established that indomethacin can cause premature constriction and can leads to closure of the fetal ductus arteriosus [4]. This can lead to serious fetal and neonatal complications including hydrops fetalis, oligohydramnios, hyperbilirubinemia, pulmonary hypertension, necrotizing enterocolitis and intraventricular haemorrhage $[5,6]$. Recent data based on serial fetal echocardiography suggest that about $50 \%$ of all fetuses whose mothers are undergoing indomethacin treatment for preterm labor develop constriction of the ductus arteriosus, with the proportion of ductal constriction after 34 weeks of gestation increasing exponentially $[7,8]$. With the advent of new oxytocin antagonist tocolytics it is still very open to debate whether the benefits of indomethacin treatment at $<32$ weeks of gestation outweigh the potential risks [9]. Diclofenac is a non-steroidal antiphlogistic drug closely related to indomethacin. Diclofenac forms part of many prescriptions that are commonly - and in some cases uncritically - used for pain relief. Until now, there has been little evidence concerning the side effects of diclofenac ingestion during pregnancy.

To the best of our knowledge this is the first case of complete mature intrauterine closure of the ductus arteriosus most likely idiopathic in nature, following mother on enoxaparin for 6months in view of which history of two medical termination pregnancy at three and half month and five months with regular follow up to doctor without any other significant medication.

\section{Case presentation}

The male new-born was $55 \mathrm{cms}$ long, HC $37.5 \mathrm{cms}$, AG $40.5 \mathrm{cms}$, and weighed 4100 grams. Immediately after the birth, baby was limp, blue and frail, with no respiration or cardiac output. The infant was stimulated, and his mouth and nose were cleaned. He was also provided with $\mathrm{AMBU}$ bag and mask ventilation with chest compression. Then infant was orally intubated, and bag and tube ventilation were continued. Adrenaline was injected into the umbilical vein and the infant's heart started beating; the initial heart rate was 100 beats per minute and later it was $>120-140$ beats per minute. With assisted ventilation, the infant turned pinkish and started responding to stimuli. APGAR was 2,5 and 9 at 1,5 and 10 mins respectively. His finger was probed in and his life parameters were assessed- the oxygen saturation was $70 \%->86 \%->93-95 \%$, AS 140-149', RR 76/55 and the temperature is $96^{\circ} \mathrm{F}$. As the baby's condition was serious, he was transported to tertiary centre (Masai Children's Hospital in Kolhapur).

Infant was hospitalised in the Neonatal Intensive Care Unit, where the mechanical ventilation was continued. The baby has peripheral oedema. While auscultation to the lungs, noticed decreased breath sounds in bilateral lower lobes. The heart rate was $120-130$ beats per minute, while the respiratory rate was 70 breaths $/ \mathrm{min}$. The saturation was between $85 \%$ and $88 \%$ (the values were comparable on all four limbs). Chest $\mathrm{x}$-ray was done which showed bilateral pleural effusion was noticed. Then echocardiogram test performed on short period (within 4 hours) showed pericardial effusion with patent foramen ovale with ballotable valvula foraminis ovalis and right to left flow, the right atrium enlarged with normal valves, severe tricuspid regurgitation, moderate mitral regurgitation and right ventricle with abnormal, hypertrophic muscularis without acceleration of blood flow. No detectable flow was shown at the ductus arteriosus.

*Correspondence to: Sandeep M, Consultant Pediatric Cardiologist, Masai Childrens Hospital, Kolhapur, Maharashtra, India, E-mail: snayak774@gmail.com

Received: May 29, 2020; Accepted: June 18, 2020; Published: June 23, 2020 
The baby needed catecholamines and was treated with Furosemide and baseline investigations along with blood culture was sent and first line antibiotics were started. On the second day of his life, $24 \mathrm{hrs}$ investigations (CRP, I.Ca ${ }^{+2}$, Sr.bil) along with LFT and coagulation profile was sent, which showed raised SGOT and SGPT along with deranged coagulopathy. Fresh frozen plasma transfusion was given. When his general condition improved inotropes and intubation were gradually weaned and stopped on 4 day of his life, then he was taken on CPAP followed by cyclical CPAP for next $36 \mathrm{hrs}$ and gradually on low flow nasal device and off oxygen on next 24 hours and followed by gradually increase of feeding daily. Follow up echocardiogram test indicated a considerable improvement in comparison to the test performed on the day one of the infant's life. ASD/PFO with left-to right shunt had no features of pulmonary hypertension. Persistent right ventricular hypertrophy was identified - the right ventricle wall was 4.5 $\mathrm{mm}(\mathrm{n}=1,4-3,6 \mathrm{~mm})$. Dyskinetic movements of the Interventricular septum were also identified. An ECG test revealed regular sinus rhythm, right axis deviation and some features of right ventricular hypertrophy. Repeat xray------ General condition being good, the baby was shifted to mother side and discharged. Baby weight at time of discharge 3384 grams. The final diagnosis was of cardiovascular disorders begun in the perinatal period - premature ductus arteriosus closure causing fetal hydrops.

It follows from the observations of the outpatient that currently he is developing normally, being active and cheerful.

\section{Discussion}

In utero closure of the fetal ductus arteriosus can occur spontaneously but is mostly caused by pharmacological agents. The ductus arteriosus is normally found only in the aorta at the place where the aortic isthmus turns into the descending aorta. The function of the ductus arteriosus is to incorporate the output of the right ventricle into the systemic circulation instead of the lungs, which are inactive in this period of life. It begins with progressive constriction of the vessel walls, which initially leads to very high flow velocities from the pulmonary trunk towards the descending aorta, which can be measured on Doppler ultrasound [10].

The most widely described drug that can fetuses indomethacin will cause immediate constriction and possibly closure; in others the ductus can remain open despite repeated doses [11]. Nowadays, events of idiopathic DA constriction and/or closure are attributed to maternal consumption of PP-rich foods in the late stages of pregnancy. The biological activity of PP is related to anti-inflammatory and antioxidant effects, which interfere with prostaglandin metabolism [12-17]. Chocolate and Mediterranean fruits and vegetables are rich in (epi) catechins, (epi) gallocatechins, (pro) anthocyanins, and other flavonoids, which are even more potent than indomethacin $[13,14]$. Several other pharmacological agents have been known to cause ductal constriction; for example, betamethasone, applied to enhance fetal lung maturation, can cause transient reversible ductal constriction [18].

In cases of severe constriction or complete closure the ductus arteriosus can no longer serve as a conduit of right ventricular outflow into the descending aorta and a much higher volume of blood will be directed towards the pulmonary arteries, which will lead to pulmonary hypertension. Ductal closure can lead to dilatation of the right ventricle, tricuspid insufficiency and potentially the development of fetal hydrops and fetal death. It has been argued that the pronounced difference in effect, in one case even observed in twins in which one infant suffered from ductal closure and the other's ductus remained open, is caused by different pathways of breakdown of the drug: by deacetylation or by demethylation $[19,20]$. In some cases, ductal closure can be reversed by withdrawing the inciting agent. Studies have demonstrated that dilatatory prostaglandins such as prostaglandin $\mathrm{E}$ are necessary to maintain the patency of the ductus arteriosus in utero [21,22]. Momma et al., demonstrated that by application of non-steroidal anti-inflammatory drugs (NSAIDs) the active process of maintaining the ductus arteriosus patency in utero could be interrupted and a constriction and/or closure can be promoted [23]. Diclofenac is an NSAID and acts by inhibiting cyclooxygenase, an enzyme that metabolizes arachidonic acid in the formation of prostaglandins [24]. Diclofenac (Voltaren) is frequently used as a painkiller; however, to the best of our knowledge, prenatal diagnosis of premature in utero closure of the ductus arteriosus following diclofenac treatment has not been reported to date. Though most reports deal with indomethacin, there has been some evidence to show that diclofenac - which as an NSAID acts in a very similar way - can have a similar effect on the fetal ductus arteriosus. In a recent report the over-the-counter NSAIDs, nimesulide and acetaminophen, were shown to cause ductal closure in a fetus [25]. Rein et al. reported a case of constriction of the fetal ductus arteriosus following maternal treatment with diclofenac for back pain at 36 weeks of gestation that was diagnosed by fetal echocardiography [26].

There are a few more case reports describing closure of the ductus arteriosus following maternal treatment with diclofenac diagnosed retrospectively by echocardiography of the neonates [27-29]. Thus, the diagnosis of premature closure of the ductus arteriosus in utero could be established only by the postnatal findings. There are several reports on spontaneous constriction and closure of the ductus arteriosus in utero [30-31].

It is difficult for doctors to suspect premature ductus arteriosus closure; it is even impossible to detect it by means of routine ultrasound examinations. Therefore, it seems to be essential to perform echocardiogram tests during the third trimester (if the results of the earlier ultrasound heart imaging were normal) in the case of abnormal images of the infant's four heart cavities, which Prof. Maria Respondek-Liberska emphasises in her numerous publications. Ultrasound echocardiogram imaging is dominated by cardiomegaly, dilated pulmonary artery, tricuspid regurgitation and pulmonary valve regurgitation, lack of detectable flow through the ductus arteriosus and sometimes hydrops fetalis.

\section{Summary}

The article presents the case of a neonatal ductus arteriosus closure detected in the postnatal period. The importance of the performance of foetal echocardiogram tests in the case of any abnormal ultrasound imaging of the four heart cavities must be emphasised. In the presented case, our attention was also drawn toward early closure of ductus arteriosus (in less than $4 \mathrm{hrs}$ ), which are often described while discussing prenatal ductus arteriosus closure.

\section{References}

1. Gewillig M, Brown SC, Catte LD, Debeer A, Eyskens B, et al. (2009) Premature foetal closure of the arterial duct: clinical presentations and outcome. Eur Heart J 30: 15301536. [Crossref]

2. Gregor M, Hodik K, Tosner J (2011) Premature closure of the ductus arteriosus. Int J Gynaecol Obstet 114: 76-88.

3. Zuckermann H, Reiss U, Rubinstein (1974) Inhibition of human premature labor by indomethacin. Obstet Gynecol 44: 787-792. [Crossref]

4. Momma K, Takeuchi H (1983) Constriction of the ductus arteriosus by non-steroidal anti-inflammatory drugs. Prostaglandins 26: 631-643. [Crossref] 
5. Ostenesen M (1994) Optimisation of antirheumatic drug treatment in pregnancy. Clin Pharmacokinet 27: 486-503. [Crossref]

6. Moise KJ, Huhta JC, Sharif DS (1988) Indomethacin in the treatment of preterm labor N Engl JMed 319: 327-331. [Crossref]

7. Moise KJ (1993) Effect of advancing gestational age on the frequency of fetal ductal constriction in association with maternal indomethacin use. Am J Obstet Gynecol 168 1350-1353. [Crossref]

8. Vermillion ST, Scrado JA, Lashus AG, Wiles HB (1997) The effect of indomethacin tocolysis on fetal ductus arteriosus constriction with advancing gestational age. Am J Obstet Gynecol 177: 256-261. [Crossref]

9. Macones GA, Robinson CA (1997) Is there justification for using indomethacin in preterm labor? An analysis of neonatal risks and benefits. Am J Obstet Gynecol 177: 819-824. [Crossref]

10. Tulzer G, Gudmundsson S, Tews G, Wood DC, Huhta JC (1992) Incidence of indomethacininduced human fetal ductal constriction. J Matern Fetal Invest 1: 267-269.

11. Gittenberger de Groot AC, van Ertbruggen I, Moulaert AJ, Harinck E (1980) The ductus arteriosus in the preterm infant: histologic and clinical observations. J Pediatr 96: 88-93. [Crossref]

12. Sridharan S, Archer N, Manning N (2009) Premature constriction of the fetal ductus arteriosus following the maternal consumption of camomile herbal tea. Ultrasound Obstet Gynecol 34: 358-359. [Crossref]

13. Z ielinsky P, Piccoli AL Jr, Manica JL (2010) Maternal consumption of polyphenolrich foods in late pregnancy and fetal ductus arteriosus flow dynamics. J Perinatol 30: 17-21. [Crossref]

14. Z ielinsky P, Busato S (2013) Prenatal effects of maternal consumption of polyphenolrich foods in late pregnancy upon fetal ductus arteriosus. Birth Defects Res C Embryo Today 99: 256-274. [Crossref]

15. Kapadia V, Embers D, Wells E, Lemler M, Rosenfeld CR (2010) Prenatal closure of the ductus arteriosus and maternal lingestion of anthocyanins. J Perinatol 30: 291-294. [Crossref]

16. Tanaka M, Miyakoshi K, Yamada M, Kadohira I, Minegishi K, et al. (2011) Functional foods for the fetus?

17. Acta Obstet Gynecol Scand 90: 1172-1173. [Crossref]

18. Enzensberger C, Wienhard J, Weichert J (2012) Idiopathic constriction of the feta ductus arteriosus: three cases and review of the literature. J Ultrasound Med 31: 12851291. [Crossref]
19. Wasserstrum N, Huhta JC, Mari GC, Sharif DS, Willis R, et al. (1989) Betamethasone and the human fetal ductus arteriosus. Obstet Gynecol 74: 897-900. [Crossref]

20. Demandt E, Legius E, Devlieger H, Lemmens F, et al. (1990) Prenatal indomethacin toxicity in one member of monozygous twins; a case report. Eur J Obstet Gynecol Reprod Biol 35: 267-269. [Crossref]

21. Friedman CA, Temple DM, Wender DF, Parks BR, Rawson JE (1991) Metabolism and disposition of indomethacin in preterm infants. Dev Pharmacol Ther 17: 1-7. [Crossref]

22. Sideris IB, Yokochi K, Van Helder T, Coceani F, Olley PM (1983) Effects of indomethacin and prostaglandin $\mathrm{E} 2, \mathrm{I} 2$ and $\mathrm{D} 2$ on the fetal circulation. $A d v$ Prostaglandin Thromboxane LeukotRes 12: 477-482. [Crossref]

23. Gersony WM (1986) Patent ductus arteriosus in the neonate. Pediatr Clin North Am 33: 545-560.

24. Momma K, Takeuchi H (1983) Constriction of the ductus arteriosus by non-steroida anti-inflammatory drugs. Prostaglandins 26: 631-643. [Crossref]

25. Rudolph AM (1981) The effects of non-steroidal anti-inflammatory compounds on fetal circulation and pulmonary function. Obstet Gynecol 58: 63-67. [Crossref]

26. Simbi KA, Secchieri S, Rinaldo M, Demi M, Zanardo V (2002) In utero ductal closure following near-term maternal selfmedication with nimesulide and acetaminophen. $J$ Obstet Gynaecol 22: 440-441. [Crossref]

27. Rein AJJT, Nadjari M, Elchalal U, Nir A (1999) Contraction of the fetal ductus arteriosus induced by diclofenac. Fetal Diagn Ther 14: 24-25. [Crossref]

28. Mas C, Menahem S (1999) Premature in utero closure of the ductus arteriosus following maternal ingestion of sodium diclofenac. Aust N Z J Obstet Gynaecol 39: 106-107. [Crossref]

29. Adverse Drug Reactions Advisory Committee (1998) Premature closure of the fetal ductus arteriosus after maternal use of non-steroidal anti-inflammatory drugs. Med $J$ Aus 169: 270-271. [Crossref]

30. Zenker M, Klinge J, Kr “ uger K, Singer H, Scharf J (1988) Severe pulmonary hypertension in a neonate caused by premature closure of the ductus arteriosus following maternal treatment with diclofenac. J PerinatMed 26: 231-234. [Crossref]

31. Samira DL, Cavall'e-Garrido T, Ryan G, Farine D, Heilbut M (1997) Isolated ducta closure in utero diagnosed by fetal echocardiography. Am J Perinat 14: 205-210. [Crossref]

32. Harlass FE, Duff P, Brady K, Read J (1989) Hydrops fetalis and premature closure of the ductus arteriosus: a review. Obstet Gynecol Surv 44: 541-543. [Crossref]

Copyright: (C2020 Sandeep M. This is an open-access article distributed under the terms of the Creative Commons Attribution License, which permits unrestricted use, distribution, and reproduction in any medium, provided the original author and source are credited. 